\title{
SOCIAL ETHICS AND LEARNING ATTITUDES OF FISHERMEN'S CHILDREN IN HAJORAN VILLAGE, SUB-DISTRICT OF PANDAN REGENCY OF CENTRAL TAPANULI
}

\author{
Halimatussakdiah \\ Surel: halimatussakdiahnst11@gmail.com
}

\begin{abstract}
This study aims to obtain data to determine the description of social ethics and attitudes of children in the State Elementary School 152980 Hajoran subdistrict of Pandan regency of Central Tapanuli. This research method using quantitative descriptive method with survey technique with 25 research samples that come from class V SD Negeri 152980 Hajoran subdistrict of Pandan regency of Central Tapanuli. Collection techniques data used through surveys by using questionnaires, and Test the validity of the questionnaire using Product Moment correlation coefficient formula while the reliability test using the formula Cronbach Alpha. In this study obtained good criteria data, namely the social ethics of students in the family, social ethics in school and social ethics in the community. And learning attitudes obtained cognitive and affective data have good criteria and psychomotor and learning activities in school and home study activities obtained data with sufficient criteria.
\end{abstract}

Keywords: Social Ethics, Learning Attitude. Children

\section{INTRODUCTION}

Currently it is needed a young generation who can continue the ideals of the nation of Indonesia. These ideals can only be achieved through education. This education should be done as well as possible, so that will get the expected results.

As the first and foremost environment for children should the family be able to be the foundation of the foundation in the formation of a good character that is used as the foundation of the development of the child's personality so as to shape the character of the nation in the future which in this case is done by the parents.
Thus, parents are the main thing that is the basis of the formation of personality and attitude of children for better development is useful for the nation and the nation. In reality, however, a family (parent) has misplaced the child. For example there are children who wear drug, killing children, selling children, and allow children to smoke. In everyday life, not a few children who imitate bad habits of adults. The habit is even harmful to children such as smoking. Children are used to seeing family members and people around them smoking.

From the interview on 16 June 2016, the teacher of SD Negeri

The Lecturer State University of Medan 
152980 Hajoran subdistrict of Pandan conducted by the researcher, stated that social ethics in school and attitude of learning of fisherman still low. Example of the ethic of the fisherman's children in talking many children who are less concerned about their teacher's back when speaking, not polite in answering questions, when met outside school most children do not want to say hello but his students hide. And after school home the child does not go home directly, but join with the parents selling fish. Examples of learning attitudes of the fisherman are also low, such as the learning time of many children who are not focused on attention to the teacher explaining, interfering with friends, some are sleeping, talking to friends, doing homework at school, some are not doing duties, School late. That's all because they at home help more parents work, there are selling and helping parents work to fish to make salted fish. So also when met at the beach when they sellannya they are indifferent and caring less.

Based on the data of the interview, the researcher obtained the average of $\mathrm{V}$ grade data collection (five) SD 152980 Hajoran subdistrict of Pandan, Central Tapanuli District with the criteria of minimum completeness (KKM) 70, that is:

\begin{tabular}{|c|c|c|c|c|c|}
\hline Tahun & \multirow{2}{*}{$\begin{array}{c}\text { Jumlah } \\
\text { Siswa }\end{array}$} & $\begin{array}{c}\text { Tuntas } \\
(\text { Orang }) \\
(\%)\end{array}$ & $\begin{array}{c}\text { Presentase } \\
(\%)\end{array}$ & $\begin{array}{c}\text { Tidak } \\
\text { tuntas } \\
(\text { Orang) }\end{array}$ & $\begin{array}{c}\text { Presentase } \\
(\%)\end{array}$ \\
\hline Tahun 2015 & 25 & 17 & 68 & 8 & 32 \\
\hline Tahun 2014 & 28 & 19 & 67,85 & 9 & 32,14 \\
\hline Tahun 2013 & 26 & 18 & 69,23 & 8 & 30,77 \\
\hline
\end{tabular}

Based on the background of the above problems can be identified some problems in this study: The low social ethics of fisherman child of SD Negeri 152980 Hajoran subdistrict of Pandan regency of Central Tapanuli.

Based on the identification of the above problems, then the problem is limited to social ethics and attitude learning of fishermen children in SD Negeri 152980 Hajoran subdistrict of Pandan regency of Central Tapanuli. The objectives of this research are: Obtained data to find out the social ethics of fisherman of Elementary School 152980 Hajoran subdistrict of Pandan regency of Central Tapanuli.

\section{RESEARCH METHODS}

The research will be conducted at SD Negeri 152980 Hajoran subdistrict of Pandan, Central Tapanuli District. The time of this research will be executed from January to March 2017. Research subject is person, place, or object observed in order to overwrite as target. Research object is subject to research. The objects in this study include: (1) Social ethics and (2) learning attitudes. The research method used in this research is quantitative descriptive method with survey techniques and data collection required by respondents to fill out the research questionnaires. This research was conducted through survey by using questionnaire as a means of collecting data, ie fill out a questionnaire that has been provided 
by researchers to examine the social ethics and attitudes of learning in the school children of fishermen. In this research instrument is done by taking data and observation by using questionnaire.

To know the validity of a questionnaire used product moment correlation formula, Arikunto (2006), as follows:

$$
r_{x y}=\frac{N \sum X Y-\left(\sum X\right)\left(\sum Y\right)}{\sqrt{\left\{N \sum X^{2}-\left(\sum X\right)^{2}\right\}\left\{N \sum Y^{2}-\left(\sum Y\right)^{2}\right\}}}
$$

Information :

$r_{x y}=$ The correlation coefficient between variables $\mathrm{X}$ and $\mathrm{Y}$

$\sum X \quad=$ Number of scores $\mathrm{x}$ (score per item)

$\sum Y=$ Total score $\mathrm{y}$ (total questionnaire score)

$N \quad=$ Number of Respondents

$\sum X^{2}=$ The sum of squares $\mathrm{x}$

$\sum y^{2}=$ The sum of squares $y$

$\sum X Y=$ Number of scores $\mathrm{x}$ and $\mathrm{y}$

To test the reliability of the instrument can be calculated with the alpha formula Arikunto (2006), namely:

$r_{11}=\left(\frac{k}{k-1}\right)\left(1-\frac{\sum \sigma_{b}{ }^{2}}{\sigma^{2}{ }_{t}}\right)$

Information :

$\mathrm{r}_{11}=$ reliabilitas instrument

$k=$ number of questions or questions

$\sum \sigma_{b}{ }^{2}=$ number of grain variances

$\sigma^{2}{ }_{t}=$ Total variance
To find the variance of the grains used the following formula:

$$
\sigma_{b}^{2}=\frac{\sum x^{2}-\frac{\sum(x)^{2}}{n}}{n}
$$

To calculate the total variance is calculated by the formula:

$$
\sigma_{t}^{2}=\frac{\sum y^{2}-\left(\frac{\sum y}{N}\right)^{2}}{N}
$$

By the criteria if $r_{11}>$ $r_{\text {tabel }}$ at a significant level of $95 \%$ or alpha $5 \%$ then the questionnaire is considered reliable, andvice versa $r_{11}<r_{\text {tabel }}$ then the questionnaire question is not reliable.

Analysis technique data that writer use is percentage data analysis (descriptive percentage) that is collected data which is result of next research questionnaire will be analyzed by put forward by Dewi (2015) with formula:

$$
\mathrm{P}=\frac{f}{n} \mathrm{x} 100 \%
$$

Information :

$\mathrm{P}=$ percentage of questionnaire assessment

$\mathrm{f}=$ number of scores obtained by students

$\mathrm{n}=$ total number of students

Analysis of the data after obtained scores and percentages, then to find the results of the survey used the following assessment criteria:

$80 \%-100 \%=$ Very good

$60 \%-79 \%=$ Good 
$40 \%-59 \%=$ Enough

$20 \%-39 \%=$ Less

Less than $20 \%=$ Very Less

\section{DISCUSSION}

Based on the results of research that has been done then obtained the survey data on social ethics of students in SD Negeri 152980 Hajoran, with the assessment of (1) social ethics in the family obtained data indicator of 711 and percentage of $79 \%$ with good criteria, (2) Schools obtained indicator data of 832 and a percentage of $76 \%$ with good criteria and (3) social ethics in the community obtained data of 350 and $70 \%$ percentage with good criteria. Can be seen in Table below:

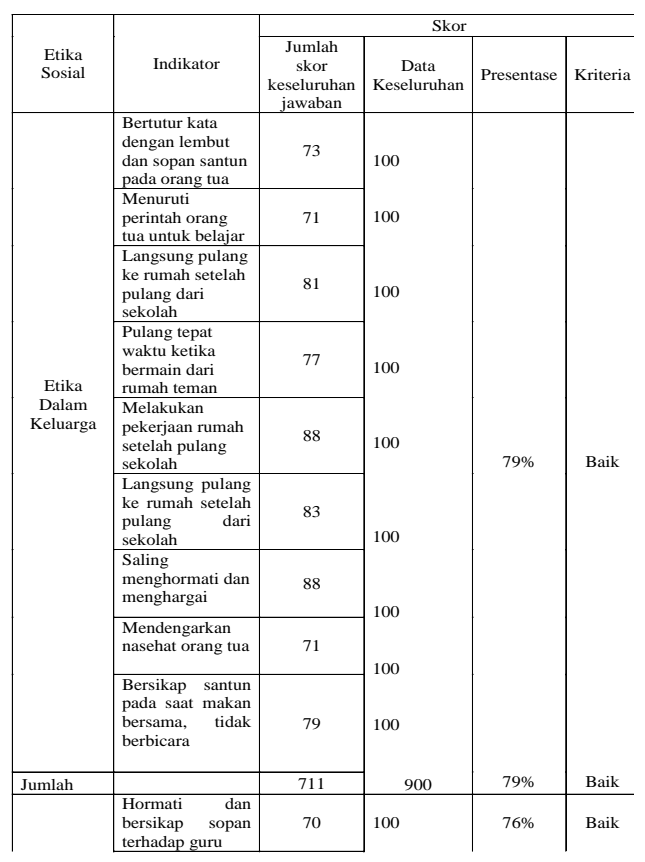

Based on the research conducted by the researcher, it is obtained the questionnaire survey data about the attitude of learning where: (1) Cognitive / Knowledge obtained by 427 indicator data and percentage of $61 \%$ with good criteria, (2) Affective/attitudes obtained indicator data of 360 and percentage $60 \%$ With good criteria, (3) Psychomotor/skill equal to 285 and $57 \%$ percentage with sufficient criteria, and (4) Activity study at school and home study activity obtained data equal to 392 and percentage $56 \%$ with enough criteria. Can be seen in Table below:

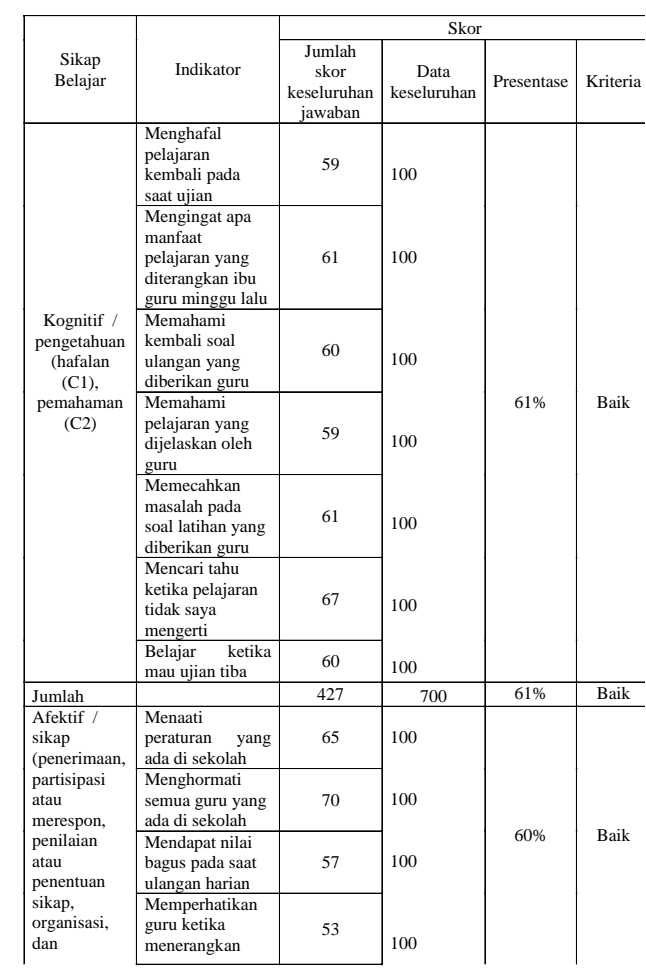

Based on the results of survey research that has been done shows that social ethics of students in State Elementary School 152980 Hajoran with good criteria that is on social ethics in the family, social ethics in school and social ethics in society. Princess (2010) states, the 
relationship between children with parents is very important, because the development of a child who first learned is a parent, from parents parents know and learn about the outside world. In the family there is a system of social interaction between the child and the father, the child with the mother or between the father and the mother. Interpersonal social interaction systems are also present within the fishing family.

In other words within the family a child can meet his needs, both physical, psychological and social needs, so that they can grow and develop well, both in the school environment and in a social environment so that a child's social ethics can thrive.

Based on the results of survey research that has been done then obtained data on student learning attitudes are cognitive with good criteria, affective with good criteria, psychomotor with sufficient criteria and student learning activities at school and at home with sufficient criteria.

\section{CONCLUSION}

Based on the results of the research results discussed in the previous chapter, it can be concluded that:

1. Social ethics of fisherman child of State Elementary School 152980 Hajoran subdistrict of Pandan regency of Central Tapanuli is good based on the data obtained that is social ethics of students in family of percentage value equal to $79 \%$, social ethics in school value percentage $76 \%$ and social ethics in social value percentage $70 \%$.

2. Learning attitude of fisherman child of Elementary School 152980 Hajoran subdistrict of Pandan regency of Central Tapanuli is good based on data obtained that is cognitive value percentage $61 \%$ and affective value percentage $60 \%$ and enough data obtained psychomotor value percentage $57 \%$ and activity learn in school and activity Home study rate of $56 \%$ percentage.

\section{BIBLIOGRAPHY}

Arifin, Z. 2011. Evaluasi Pembelajaran Prinsip Teknik Prosedur. Bandung: Remaja Rosdakarya.

Arikunto, Suharsimi. 2006. Prosedur Penelitian Suatu Pendekatan Praktek. Jakarta: Rineka Cipta.

Ariswandha, Y.M., Pola Asuh Orang Tua pada Keluarga Nelayan Tradisional di Dusun Karanganom Kelurahan Karangrejo Kabupaten Banyuwangi Tahun 2013. FKIP Universitas Jember (Skripsi).

Azwar, S. 2011. Sikap Manusia Teori dan Pengukurannya. Edis ike 
2. Yogyakarta: Pustaka Pelajar.

A. Wawan, dkk. 2011. Teori dan Pengukuran Pengetahuan, Sikap, dan Perilaku Manusia. Cetakan II. Yogyakarta: Nuha Medika.

2011/04/30/sikap-belajar-pesertadidik/. Di Akses 16/12/2016

Bernando. 2012. Pengertian Penilaian Kognitif, Afektif, dan Psikomotorik menurut Bloom.

http://bernandohutajulu.blogsp ot.co.id/2012/10/pengertianpenilaian-kognitif-

afektif.html. Di Akses 23/10/2016

Djamarah, Syaiful. 2011. Psikologi Belajar Edisi II. Jakarta: Rineka Cipta.

Dewi,

Rosmala.

2015

Profesionalisasi Guru Melalui Penelitian Tindakan Kelas. Medan: Penerbit Unimed Press.

Evelin, S. 2010. Teori Belajar dan Pembelajaran. Bogor:

Penerbit Ghalia Indonesia.

Fabio. 2011. Aktivitas Belajar di Rumah terhadap Prestasi di Sekolah. http://fabioblackwhite.blogspo t.co.id/2011/11/aktivitasbelajar-dirumahterhadap.html. Di Akses $11 / 12 / 2016$

Fedri. 2011. Etika Sosial. http://masfedri.blogspot.co.id/ 2011/05/etika-sosial.html. Di Akses 11/12/2016

Fitria, R. 2011. Sikap Belajar Peserta Didik.

https://rizcafitria.wordpress.co $\mathrm{m} /$

Habbibullah. 2014. Faktor yang Mempengaruhi Prilaku Etika dalam Etika. https://www.aahabbibullah.rap pertasikmalaya/posts/6156816 78507899. Di Akses $4 / 12 / 2016$

Hamalik, Omar, 2006. Metode Belajar dan Kesulitankesulitan Belajar. Bandung: Tarsito.

Heri, E. 2014. Etika dalam Keluarga. http://enjangheri.blogspot.co.i d/ 2014/04/etika-dalamkeluarga.html. Di Akses $16 / 12 / 2016$

Istarani, Intan. 2015. Ensiklopedi Pendidikan. Medan: CV. Iscom.

Jihad, Asep, dkk. 2013. Evaluasi Pembelajaran. Yogyakarta: Multi Pressindo.

Khairunnisa, Hemas Farah. 2014. Studi Deskriptif Children Well-Being pada Anak yang Bekerja Sebagai Buruh Nelayan di Desa Karangsong Indramayu. Fakultas Psikologi Universitas Islam Bandung/

Lidia. 2016. Etika Berdagang. https://www.jurnalasia.com/op ini/etika-berdagang/. Di Akses $16 / 12 / 2016$ 
Lonto, Lexi. 2013. Etika Kewarganegaraan.

Yogyakarta: Penerbit Ombak.

M. Dalyono. 2009. Psikologi Pendidikan. Jakarta: Rineka Cipta.

M. Kharisun. Karakteristik dan Peran

Istri Nelayan dalam

Pendapatan Keluarga di Kota

Pekalongan Tahun 2014.

FEB. Universitas Diponegoro

Semarang (Skripsi).

Masri. 2010.

Identifikasi

Karakteristik Sosial, Ekonomi, dan Budaya Masyarakat Nelayan Sungai Limau di Kabupaten Padang Pariaman dalam Penyediaan Perumahan Permukiman Tahun 2010. Program Pascasarjana. Universitas Diponegoro Semarang (Tesis)

Nisa', Khairun. (2016). Pola Asuh Para Nelayan dalam Pembentukan Karakter Anan (Studi di Desa Legung Timur Batang-batang Sumenep Madura). Youyakarta: Pascasarjana UIN Sunan Kalijaga.

Rahmawati, S., Genjik, S.B., Rustiyarso. Pengaruh Penghasilan Orang Tua Terhadap Pendidikan Anak. Kalimantan Barat: Program Studi Pendidikan Ekonomi FKIP UNTAN.
Rismawaty. 2008.

Kepribadiandan Etika Profesi. Yogyakarta: Graha Ilmu

Salam, Burhanuddin. 2000. Etika Individual Pola Dasar Filsafat Moral. Jakarta: PT. Rineka Cipta.

Sardiman, A.M. 2014. Interaksi dan Motivasi Belajar Mengajar. Jakarta: Rajawali Pers.

Slameto. 2013. Belajar dan Faktorfaktor yang Mempengaruhinya. Jakarta: PT. Rineka Cipta.

Sudarsono, FX. 2007. Pendidikan Etika yang Terpinggirkan dan Terlupakan. Dinamika Pendidikan. No. 1/ Th. XIV / Mei 2007

Syah, Muhibbin. 2010. Psikologi Pendidikan. Bandung: PT. RemajaRosdakarya

Sugiyono. 2007. Metode Penelitian Pendidikan. Bandung: Alfabeta.

Shocib, M. 2000. Pola Asuh Orang Tua. Jakarta: Rineka Cipta.

Widoyoko, S.E.P. 2012. Teknik Penyusunan Instrumen Penelitian. Cetakan Pertama. Yogyakarta: Pustaka Pelajar. 